\title{
Tangible Heritage of the Historical Stonework Centre in Brusno Stare in the Roztocze Area (SE Poland) as an Opportunity for the Development of Geotourism
}

\author{
Teresa Brzezińska-Wójcik ${ }^{1}$ (D) - Ewa Skowronek ${ }^{1}$ \\ Received: 4 December 2018 / Accepted: 8 January 2020 / Published online: 27 January 2020 \\ (C) The Author(s) 2020
}

\begin{abstract}
The investigation relates to the human-environment relationships in the development of geotourism. The study is focused on the stonemasonry heritage of the historical Stonework Centre in Brusno Stare - a former, now non-existent village, abandoned after World War II, in SE Poland. The "stonemasonry" heritage was included into the potential Kamienny Las na Roztoczu Geopark. Preparation of these usable, sacral, sepulchral objects, as well as the quarry requires geological and historical interpretation to become cultural geosites. The aim of the present study is to highlight the importance of the interpretation of these objects based on the combination of knowledge in the fields of geology, history, and culture. This objective has been achieved by querying available literature, inventory, and assessments of geosites. The conceptual spatial-temporal model has been proposed to illustrate the holistic approach to the potential cultural geosites considered in the manuscript. The results obtained in the study indicate the scientific, educational, and geotouristic potential of the stonemasonry heritage of the ancient Stonework Centre of Brusno Stare. Popularization and promotion of these objects is needed to make them attractive cultural geosites and contribute to the development of geotourism in the Roztocze area.
\end{abstract}

Keywords Geoheritage $\cdot$ Stonework $\cdot$ Cultural geosites $\cdot$ Geotourism $\cdot$ Roztocze area

\section{Introduction}

The research issue undertaken in the study is associated with the attempts to create the Kamienny Las na Roztoczu Geopark (Krapiec et al. 2012). When the concept of geopark was being developed in 2010-2011, a detailed inventory of geosites was made. The project of the geopark was commissioned by the Ministry of the Environment (at present the Ministry of Climate). It was

This article is part of the Topical Collection on Geoheritage and Conservation: Modern Approaches and Applications Towards the 2030 Agenda, IX ProGEO Symposium, Poland, 25-28th June, 2018

Teresa Brzezińska-Wójcik

tbrzezin@ poczta.umcs.lublin.pl

Ewa Skowronek

ewa.skowronek@poczta.umcs.lublin.pl

1 Faculty of Earth Sciences and Spatial Management, Maria

Curie-Sklodowska University, al. Krasnicka 2d,

20-718 Lublin, Poland designed in cooperation between researchers from the AGH University of Science and Technology in Kraków, Polish Geological Institute-National Research Institute Carpathian Branch in Kraków, Institute of Nature Conservation of the Polish Academy of Sciences in Kraków, and Maria Curie-Sklodowska University in Lublin. The spatial range of the investigations covered the central and southern parts of the Roztocze area in SE Poland (Fig. 1a). Twentyfive out of the 166 geosites inventoried by the first author of the article are related to the ancient Stonework Centre in Brusno Stare (Fig. 1b and Table 1). They include local quarries as well as utilitarian (elements of buildings) and artistic (tombstones, statues, roadside crosses) sites with stone products, mainly from the nineteenth century.

Stone objects produced in the ancient Brusno Stare Stonework Centre (Mazur 2008) are an important element of the local geoheritage. Some of stone objects (the wall with gates, a mortuary building, and historical tombstones) are part of the Greek Catholic tserkva (church) complex in Radruż village (Fig. 1b) included in the UNESCO World Heritage List in 2013 (UNESCO World Heritage List. http://whc.unesco.org/ en/list/1424). 


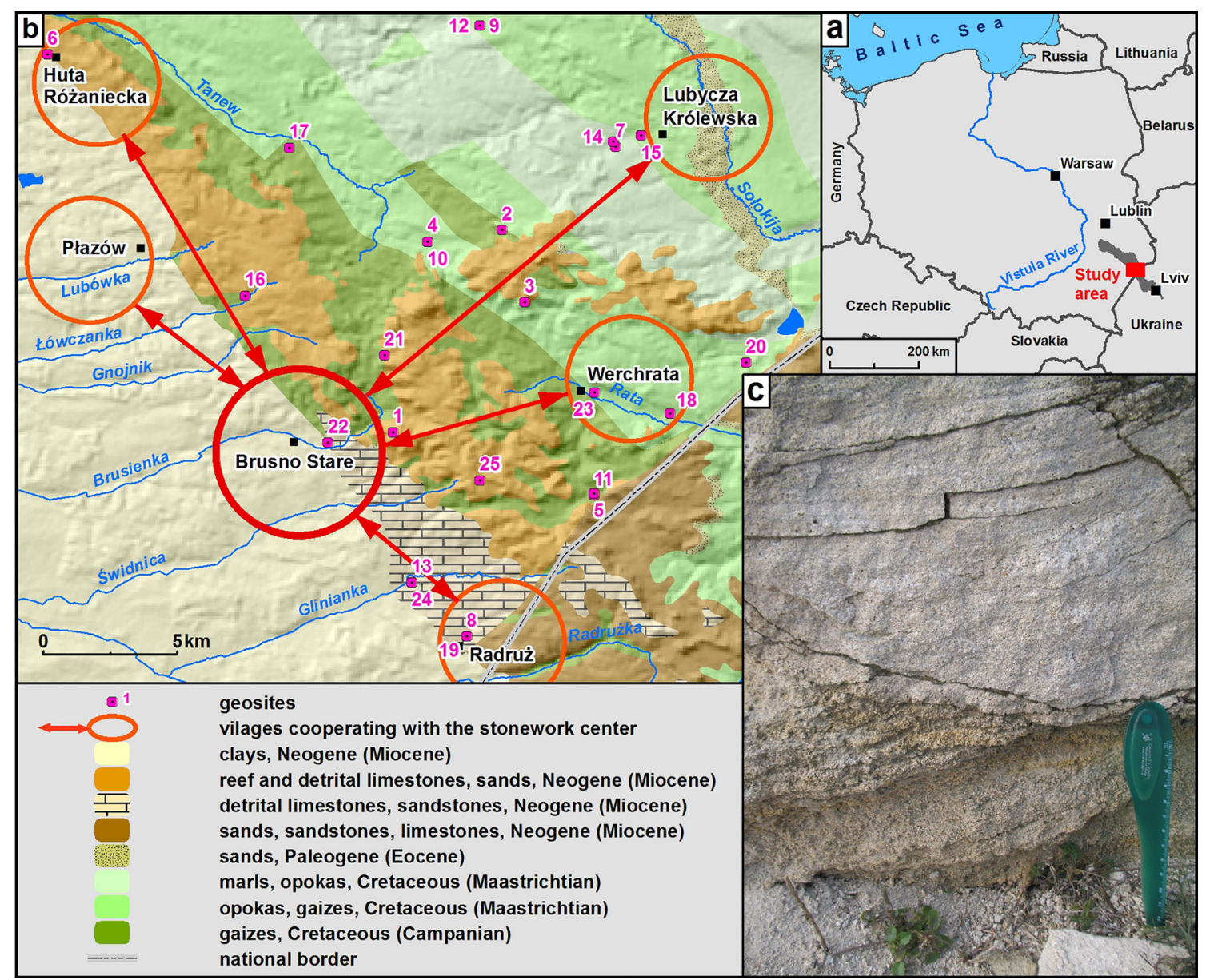

Fig. 1 (a) Location map. (b) Geological map of the southern part of the Roztocze area and the range of influence of the ancient Stonework Center in Brusno Stare (based on: Musiał 1987, Gutowski et al. 2005, Mazur
2008). The names of geosites are in Table 1. (c) Miocene detrital limestones in the quarry on Brusno Hill. Photograph by Teresa BrzezińskaWójcik
In this study, the quarries and stonework objects manufactured in Brusno Stare may become cultural geosites. The importance of these cultural geosites is evidenced by the relationship between geological resources and the use thereof by humans (e.g. Lugon and Reynard 2003; Panizza and Piacénte 2003; Pralong 2004; Reynard et al. 2009; Zgłobicki et al. 2015).

When included in the geotourism offer, they can expand knowledge about the ancient Stonework Centre in Brusno Stare, contribute to promotion of its products, and consequently play a role in protection of the local geoheritage through a combination of geoconservation, geohistory, and geointerpretation1 (likewise the 3G's concept after Hose 2012). This is in line of the research trend consisting in a holistic approach to geotourism (Pralong 2006; Hose 2012; Dowling 2013; Gordon 2012, 2018; Telecka 2017).

The main objective of the study is supported by specific aims: (1) characterization of geological resources promoting the development of the ancient Stonework Centre in Brusno Stare, (2) presentation of the history of the Stonework Centre, (3) characterization of the traits and forms of stonework products from Brusno Stare, and (4) quantitative assessment of inventoried cultural geosites.

The tasks addressed in the study will contribute to popularization of the stonemasonry heritage. Simultaneously, through the consolidation of the public memory of the ancient Stonework Centre, they may prompt actions for preservation and conservation of its heritage.

\section{Methods}

Primary and secondary data sources were used to achieve the study goals. The primary sources included 25 geosite inventory cards. The secondary data sources comprised publications related to geotourism, geoheritage, and historical geosites, as well as publications on the history and function of the ancient Brusno Stare Stonework Centre.

During the field inventory events, each geosite was documented in terms of its location (geographical information system, GIS; town, commune), genesis, physical traits (size, surface area, geological/historical age, lithology, and rock 
Table 1 Final scores of cultural geosites connected with the historical Stonework Centre in Brusno Stare

\begin{tabular}{|c|c|c|c|c|c|c|}
\hline No. & Name of geosite & Type of object & $\begin{array}{l}\text { Scientific } \\
\text { Value }\end{array}$ & $\begin{array}{l}\text { Potential } \\
\text { Educational } \\
\text { Use }\end{array}$ & $\begin{array}{l}\text { Potential } \\
\text { Touristic Use }\end{array}$ & $\begin{array}{l}\text { Degradation } \\
\text { Risk }\end{array}$ \\
\hline 1 & Miocene organic limestone in the quarry on Brusno Hill & Quarry & 185 & 235 & 220 & 165 \\
\hline 2 & Remains of a farm stone fence in Huta Lubycka & Usable & 50 & 95 & 155 & 85 \\
\hline 3 & $\begin{array}{l}\text { Remains of stone residential and farm buildings } \\
\text { (fence walls, cellars, wells) of the Greek Catholic } \\
\text { church complex on Monaster Hill }\end{array}$ & & 55 & 95 & 155 & 85 \\
\hline 4 & Stone fence around the Greek Catholic church in Wola Wielka & & 60 & 135 & 185 & 130 \\
\hline 5 & $\begin{array}{l}\text { Ruins of the Greek Catholic church complex and gravestones } \\
\text { in the cemetery in Dziewięcierz-Moczary }\end{array}$ & Sacral & 60 & 125 & 185 & 130 \\
\hline 6 & $\begin{array}{l}\text { Ruins of the Greek Catholic church and gravestones in } \\
\text { Huta Różaniecka }\end{array}$ & & 60 & 125 & 185 & 130 \\
\hline 7 & Ruins of the Greek Catholic church and gravestones in Kniazie & & 60 & 105 & 165 & 100 \\
\hline 8 & $\begin{array}{l}\text { Limestone wall and tombstones in the Greek Catholic church } \\
\text { complex in Radruż }\end{array}$ & & 130 & 145 & 185 & 130 \\
\hline 9 & Limestone gravestones at the Greek Catholic church in Bełżec & & 50 & 120 & 180 & 125 \\
\hline 10 & $\begin{array}{l}\text { Limestone gravestones at the Greek Catholic church in } \\
\text { Wola Wielka }\end{array}$ & & 60 & 125 & 185 & 130 \\
\hline 11 & Limestone Jordan Chapel in Dziewięcierz-Moczary & & 60 & 95 & 155 & 85 \\
\hline 12 & Limestone gravestones in the cemetery in Bełżec & Sepulchral & 50 & 130 & 190 & 140 \\
\hline 13 & Limestone gravestones in the cemetery in Horyniec-Zdrój & & 55 & 125 & 185 & 130 \\
\hline 14 & Limestone gravestones in the cemetery in Kniazie & & 55 & 105 & 165 & 100 \\
\hline 15 & limestone gravestones in the cemetery in Lubycza Królewska & & 60 & 125 & 185 & 130 \\
\hline 16 & Limestone gravestones in the cemetery in Łówcza & & 55 & 105 & 165 & 100 \\
\hline 17 & Limestone gravestones in the cemetery in Narol & & 50 & 125 & 185 & 130 \\
\hline 18 & Limestone gravestones in the cemetery in Prusie & & 55 & 125 & 185 & 130 \\
\hline 19 & $\begin{array}{l}\text { Limestone gravestones in the Greek Catholic cemetery } \\
\text { in Radruż }\end{array}$ & & 60 & 115 & 175 & 115 \\
\hline 20 & Limestone gravestones in the cemetery in Siedliska & & 55 & 125 & 185 & 130 \\
\hline 21 & Limestone gravestones in the cemetery in Stara Huta & & 50 & 95 & 155 & 85 \\
\hline 22 & $\begin{array}{l}\text { Limestone gravestones in the Greek Catholic cemetery } \\
\text { in Brusno Stare }\end{array}$ & & 60 & 95 & 155 & 85 \\
\hline 23 & Limestone gravestones in the cemetery in Werchrata & & 60 & 125 & 185 & 130 \\
\hline 24 & Limestone Poniński chapel in the cemetery in Horyniec-Zdrój & & 55 & 125 & 185 & 130 \\
\hline 25 & Temple of the Sun in Nowiny Horynieckie & Place of worship & 80 & 115 & 155 & 85 \\
\hline
\end{tabular}

Own study based on the results of field inventory

structure), and current status (form of ownership, protection status, preservation state, accessibility for visitors, location relative to existing infrastructure). Additionally, photographic documentation was collected for each of the 25 inventoried cultural geosites.

The method proposed by Brilha (2016) was used for the quantitative assessment of the cultural geosites in the Roztocze area. This is a specific method to quantify the values, creating an integrated proposal for the quantitative assessment of all types of geosites. The quantification process was based on 37 criteria ( 7 criteria were used for scientific value, 12 for education values, 13 for touristic values, 5 for degradation risk) with numerical parameters ranging from 1 to 4 (Brilha 2016). The final value for each cultural geosite derives from the weighted sum of each criterion, with a maximum score of 400 points. Each criterion has a specific weight for the scientific value (SV), potential educational use (PEU), potential touristic use (PTU), and degradation risk (DR). Based on the numerical result, the values and the degradation risk of the cultural geosites were classified into one of four classes: very low, low, moderate, and high (Tables 1 and 2).

Additionally, a conceptual spatial-temporal model illustrating the holistic approach to unique cultural geosites was proposed. Cartographic methods were employed as well to demonstrate geographic position of the studied area, the geospatial distribution of the analysed geosites in relation to geological settings, and the range of influence of the ancient Stonework Centre in Brusno Stare (Fig. 1). 
Table. 2 Classification of scientific (SV), educational (PEU), touristic (PTU) values, and degradation risk (DR) into four classes: very low, low, moderate, and high

\begin{tabular}{ll}
\hline Range & Values and degradation risk \\
\hline $0-100$ & Very low \\
$101-200$ & Low \\
$201-300$ & Moderate \\
$301-400$ & High \\
\hline
\end{tabular}

Adapted from Brilha (2016)

\section{Study Area}

The ancient Stonework Centre was located in Brusno Stare village in the Roztocze area. The region is situated in southeastern Poland and north-western Ukraine. It appears in the landscape as a distinct upland range spreading from NW to SE, between Kraśnik (Poland) and Lviv (Ukraine) (Fig. 1a). In Poland, three subregions with diverse natural features are distinguished - Western Roztocze, Central Roztocze, and Eastern Roztocze.

Brusno Stare was located in Eastern Roztocze. This area is characterized by the highest altitudes in the region - 390 m a.s.l. (Wielki Dział, Kragły Goraj Hills). The main terrain forms include flat-topped hills, tablelands, dry valleys, ravines, and karst forms (caves) associated with the physical and chemical features of rocks and sediments (see Geological Settings). For the purposes of the local stonemasonry, Miocene detrital limestones and sandstones were excavated in the quarry on Brusno Hill (Fig. $1 \mathrm{~b}$ and $\mathrm{c}$, and Table 1).

The historical context is also important from the point of view of the function of the ancient Stonework Centre in Brusno Stare village (Fig. 1b). Before World War II, the area of Eastern Roztocze was inhabited by different nationalities, e.g. Poles, Ukrainians, Jews, and Germans. They contributed to the specific traits of the cultural landscape (type of settlement network, land-use structure, sacral object scenery) (Skowronek et al. 2003). The huge social and economic changes on this territory took place after the World War II and after the changes in the course of the eastern border of Poland (Snyder 1999). As a consequence of mass displacements driven by the communist governments of Poland and the Ukrainian SRR, including the Operation "Vistula", the ethnic structure of the population was unified, and the number of inhabitants decreased drastically. A number of villages and settlements situated near the border disappeared at that time. Forests started to occupy a part of the former settlements and agricultural lands (Skowronek and Furtak 2009). The contemporary Eastern Roztocze is characterized by low population density, an irregular settlement network, a low industrialisation rate, and poor development of urbanization (Wesołowska and Flaga 2018).

\section{Geological Settings}

The Roztocze region located within the Trans-European Suture Zone (TESZ) was included in the study (Berthelsen 1992). Its current features are associated with the MesoCenozoic stage of development. It was unevenly raised in the late Miocene-Pliocene as a large-scale flower structure covering the original Meso-Cenozoic synclinal area (Jankowski and Margielewski 2015). This structure, which is rooted into deep substrate, creates fault zones of different rank, enclosing and dissecting the area of Roztocze.

The formations exposed on the Roztocze surface are dominated by Late Cretaceous carbonate and carbonate-siliceous rocks (93-65 million years ago). They are characterized by variable thickness ranging from 600 to $900 \mathrm{~m}$ in the western part of Roztocze region to $1400 \mathrm{~m}$ in the south (Gutowski et al. 2005). The Cretaceous rocks are covered by heavily eroded shallow water sediments of Paleogene (Eocene, 5534 million years ago) and Neogene (Miocene, 8-12 million years ago) seas (Fig. 1b). The oldest formations, i.e. Eocene sands and sandstones, are characteristic for the eastern part, whereas the younger Miocene limestones and coquina beds, as well as sands and sandstones, are typical for the southwestern part of the region (Wysocka et al. 2007). Pleistocene deposits are present only on hills (residual moraine covers of Mindel and Riss glaciations) and in deep valleys (sands, gravels, and clays with a thickness of over $30 \mathrm{~m}$ ) (Brzezińska-Wójcik and Kociuba 2001). Aeolian formations, i.e. sands, also forming dunes, are characteristic for the depressions and valleys of central Roztocze, whereas loess covers are typical of the western part of the region.

In Eastern Roztocze, Miocene detrital limestones and sandstones were used in the ancient Brusno Stare Stonework Centre. The Miocene limestones are composed of bioclasts (fragments of algae and mollusc shells) on average accounting for $70-90 \%$ of the rock. Its characteristic trait is the variable content of quartz grains throught the vertical section (up to $10 \%$ ). Its chemical composition is dominated by $\mathrm{CaCO}_{3}$ (over $90 \%$ ), whereas the content of $\mathrm{SiO}_{2}$ ranges from 10 to $30 \%$. In terms of physical characteristics, limestones are characterized by high apparent density (about $1.9 \mathrm{Mg} / \mathrm{m}^{3}$ ), porosity (35.68\%), mostly moderate and high absorbability (14.25\% weight absorbability; $25.25 \%$ volumetric absorbability), poor frost resistance (12-25 cycles), and high abrasiveness, especially after extraction (Musiał 1987). Owing to the two latter features, the rocks were an easy-to-handle stonework material; nevertheless, when subjected to "ageing" in natural weather conditions, the rocks became durable and resistant to external factors. They were mainly used for production of tombstones, statues, and roadside crosses. 
Anisomerous limy sandstones shaw variable contents of $\mathrm{CaCO}_{3}(38-64 \%), \mathrm{SiO}_{2}(30-50 \%)$, and $\mathrm{CaO}(20-30 \%)$. They are massive rocks ( $5.99 \%$ porosity) with a dense texture and non-homogeneous material arrangement. They are characterized by low absorbability (1.28\% weight absorbability; $3.22 \%$ volumetric absorbability) and high compressive strength (80.22 MPa dry; 60.52 MPa soaked) (Musiał 1987). Hence, it was possible to use the rock as a building material.

The excavation of these rocks was facilitated by their shallow location and the natural dimensionality associated with the joint fracture network and diversity of layers. Therefore, the relatively easy extraction and processing of the rocks made it possible to produce usable and artistic stonework.

\section{Geoheritage Context of Ancient Brusno Stare Stonework Centre}

Brusno Stare was first mentioned in the literature in 1444 (Jawor 2000). From the very beginning, it combined many nationalities and cultures - Polish, Ruthenians, and Jewish, later also Germans. Extraction and processing of local rocks was the main activity of the local community, besides agriculture. The village was named after the word "brus" which in Polish meant fine-grain sandstone or a grinding stone (Lew 1967). The excavation of rocks was probably initiated in the Late Middle Ages (Lew 1967). It is known that, in the middle of the sixteenth century, millstones and quern stones were produced in Brusno Stare (Kawałko 1995) and local rocks were extracted for construction of the developing villages and settlements in Eastern Roztocze (Mazur 2008). From the sixteenth century, masonry workshops associated with the emerging Stonework Centre were established, for example in the towns of Lubycza Królewska and Radruż, Płazów, Werchrata, and of Huta Różaniecka villages (Fig. 1b). Former stonemasons, also referred to as "miners", were farmers, and the stone craft was their additional occupation and a source of income. Stonework skills were passed from father to son, thus creating the local community tradition and ensuring the "folk" nature of this activity (Mazur 2008).

The status of the ancient Brusno Stare Stonework Centre increased at the turn of the nineteenth and twentieth centuries together with the specialization in production of artistic tombstones. This was promoted by the process of transferring burial grounds out of development areas (initiated at the end of the eighteenth century), the enfranchisement of the peasantry, and the demand for statues and roadside crosses (Kawałko 1995). Artistic crafts reflected the characteristics of the population that had been living in three villages since the Josephine colonization (second half of the eighteenth century). The Austrian authorities divided the former village into two parts, Brusno Stare and Brusno Nowe, and established a German settlement DeutschBach between them. Brusno Stare was mainly inhabited by Greek Catholic Ruthenians, Roman
Catholic Poles, and Jews. In Brusno Nowe, there were mainly Poles and Ruthenians, whereas DeutschBach was first inhabited by Germans affiliated to the evangelical denomination and then by Poles and Ruthenians. Before World War II, the three villages were interconnected and had over 2300 residents (Sulimierski et al. 1881, 1884; Skorowidz miejscowości Rzeczpospolitej Polskiej 1924).

During the heyday of the Stonework Centre, its products were sold extensively throughout vast areas which now belong to south-eastern Poland and western Ukraine, reaching Rzeszów city and Kolbuszowa town in the west, Przemyśl city and Mościska town in the south, areas close to Lviv city, Busk, and Żółkiew towns in the east, and Zamość city, as well as Tomaszów and Bełz towns in the north (Reinfuss 1989; Mazur 2008). This situation persisted until the end of World War II, when the Brusno Stare and DeutchBach villages were decimated. The decline was a result of warfare and political decisions made in the final phase of the war. In 1945, the village was burnt down. Some residents were relocated to the former Soviet Union, and others were transferred to the Recovered Territories during Operation Vistula in 1947 (Snyder 1999). Brusno Stare ceased to exist, and the settlement and cultural continuity of the area was interrupted (Skowronek and Furtak 2009). After the political situation had stabilized, the few remaining residents of the former Brusno Stare village settled down in Brusno Nowe and tried to continue the artistic stonework traditions until the 1960s (Reinfuss 1989) yet unsuccessfully. Nowadays, Miocene limestones are extracted in the quarry on Brusno Hill by private owner and used as a building material and for local production of burnt lime (Fig. 2a).

\section{Traits and Forms of the Brusno Stare Stonework Centre Geoheritage}

The results of the inventory of the geosites carried out as part of the Kamienny Las na Roztoczu Geopark project indicate that the heritage of the centre created over centuries includes a variety of products: usable objects, elements of architecture and construction, and artistic craftwork.

The first group is represented by remains of stone residential and farm buildings (fence walls, cellars, wells) (Table 1 and Fig. 2b), which were produced in the nineteenth century. Nowadays, they are dispersed across the area and exhibit different states of preservation.

Another group comprises sacral and secular buildings or their fragments. These include ruins of a Basilian Monastery on Monaster Hill near Werchrata dated to the end of the seventeenth century, foundations of the church and belfry in Wola Wielka village from 1775, ruins of St. Paraskevi Greek Catholic stone churches in Kniazie village (with a belfry and stone posts in the fence) from 1806, ruins of St. Nicolaus Greek Catholic church in Huta Różaniecka from 1835 




Fig. 2 Cultural geosites associated with the Stonework Centre in Brusno Stare. (a) View of the quarry of Miocene detrital limestones on Brusno Hill (geosite no 1). (b) Stone fence around the Greek Catholic church in Wola Wielka (geosite no 4). (c) Ruins of the Greek Catholic Church and gravestones in the cemetery in Huta Różaniecka (geosite no 6). (d) Ruins of the Greek Catholic church of Elevation of the Holy Cross in Dziewięcierz-Moczary (geosite no 5). (e) Stone wall at the gate around the Greek Catholic church in Radruż (Wooden Tserkvas of the Carpathian
Region in Poland and Ukraine - UNESCO World Heritage List. http:/ whc.unesco.org/en/list/1424) (geosite no 8). (f) Limestone gravestones in the cemetery in Lubycza Królewska (geosite no 15). (g) Limestone gravestones in the cemetery in Werchrata (geosite no 23). (h) Examples of nineteenth century crosses decorated with bas-reliefs of Christ and with relief images of Christ and two Marias in the cemetery in Radruż (geosite no 19). Photograph a, e, and h by Ewa Skowronek and b, c, d, f, and $g$ by Teresa Brzezińska-Wójcik 
(Table 1 and Figs. 1a and 2c), ruins of the Greek Catholic church of elevation of the Holy Cross in DziewieccierzMoczary village from 1838 (Fig. 2d), and Poniński's tomb chapel in Horyniec-Zdrój village. The stone fences of sacral buildings, such as those in Łówcza and Wola Wielka villages (Fig. 2b), Radruż village (Fig. 2e), and Dziewięcierz-Moczary (Table 1 and Fig. 1b) are characteristic of the area's heritage. The rocks excavated in the area of Brusno Stare were also used to build drives and country roads, e.g. from Jarosław to Bełżec in 1861-1863 (Kawałko 1995) in Galicia, i.e. a historical and geographical region between Central and Eastern Europe.

Arts and crafts have become the hallmark of Brusno Stare. They are primarily sepulchral works, mainly sacral sculptures, associated with the Greek Catholic and Roman Catholic rites. Additionally, there are examples of artistic tombstone work commissioned by the former German evangelical minority and matzevah stones in Jewish cemeteries.

The field inventory reveals that the sixteenth-century crosses in Prusie village (Table 1 and Fig. 1b) are the oldest artefacts of artistic stonework. Their shape resembles the Maltese cross. They were manufactured in this form until the first half of the nineteenth century. Similar crosses can be found in the cemeteries in Brusno Nowe, Dziewięcierz-Moczary, Horyniec, Huta Różaniecka (Fig. 2d), Kniazie, Lubycza Królewska (Fig. 2f), Łówcza, Płazów, Siedliska, Werchrata (Fig. 2g), and Wola Wielka and in cemeteries at Greek Catholic churches, e.g. in Bełżec and Radruż villages, or cemetery remnants in Brusno Stare (Table 1 and Fig. 1b). Crosses with a widened vertical beam decorated with bas-reliefs depicting Christ appeared in the first half of the nineteenth century. The crosses have trefoilshaped or bevelled arm edges. They can be found in all the aforementioned cemeteries. At the end of the nineteenth century, crosses were made of a single block of limestone; they were placed on pillars with bas-relief images of Christ or Christ with two Marias (Fig. 2h), and their arms were straight, trefoilshaped, and bevelled. Such gravestones can be found in all Greek Catholic cemeteries in Eastern Roztocze, besides the one in Prusie village.

At the beginning of the twentieth century, another type of tombstones appeared, i.e. a cross on a pedestal resembling a pole. Pedestals in the form of stone mounds and crosses resembling wood with bark-shaped carving were introduced as well. Such tombstones can be found in the cemeteries in Radruż, Werchrata, Brusno Nowe, Lubycza Królewska, Łówcza, Horyniec, Bełżec, and Kniazie (Table 1 and Fig. 1b).

A separate group was represented by Jewish matzevah stones, i.e. grave stelae, which became popular in the eighteenth century. Most of them are a collective work of Christian stonemasons from Brusno Stare and Jewish craftsmen, i.e. the authors of Hebrew inscriptions (Reinfuss 1989). In the nineteenth century, the matzevah stones became more richly ornamented. Motifs connected with the rich symbolism of Jewish culture such as lions, birds, crowns, palms in the gesture of blessings, and candlesticks were used (Mazur 2008).

A well-preserved group are the evangelical tombstones in the cemetery in Brusno Nowe, originating from the $1820 \mathrm{~s}$ and $1840 \mathrm{~s}$. Besides the typical crosses, there are also stelae (Mazur 2008).

There are also tombstones and monuments made during World War I, for instance, the crosses from 1917 with German inscriptions on the site of the former Basilian Monastery on the Monaster Hill and the monument commemorating Polish soldiers fallen in the battles in 1918-1919 in Horyniec-Zdrój.

The rich stonework assortment from Brusno Stare also comprises numerous stone crosses as well as sculptures of saints and chapels, which were commonly located at roads and crossroads. They were erected as an expression of gratitude for regained health or abolition of serfdom, for example, in the Łówcza and Radruż villages, and at murder, suicide, and defeat sites. There are also penitential and grave figures (Kawałko 1995; Mazur 2008) as well as shrines associated with rites such as the Feast of Epiphany in Dziewięcierz-Moczary village.

It is important to cherish the memory of the outstanding stonemasons from Brusno Stare - for instance, one of the most famous craftsmen, Grzegorz Kuźniewicz (1871-1948), called the "Artist". He made many tombstones and monuments in the Polish part of Roztocze and in the USA (1907-1912) (Kawałko 1995).

The diversity of Brusno Stare stonework was also influenced by the presence of Jews. They owned or rented large quarries (e.g. before World War I, the quarries were rented by Szmaja Bienstock and Józef Reichbach in Brusno Stare and Azriel Klingsberg in Radruż). Additionally, they produced matzevah tombstones (e.g. in the first decade of the twentieth century, Jankiel Bienstock and Jan Grabowiec) or made millstones (e.g. at the beginning of the twentieth century, Szmaja Bienstock and Józef Reichbach, cf. Olszewski (1912).

This report confirms the view that the stonemasonry heritage in Eastern Roztocze is a testimony to the multicultural character of the region. Despite the severe damage left by World War II, the state of preservation of Brusno Stare heritage at the beginning of the twenty-first century can be regarded as satisfactory.

\section{Results}

The inventoried cultural geosites are located in Eastern Roztocze, approximately $20 \mathrm{~km}$ away from the Stonework Centre in Brusno Stare (Fig. 1b).

The final values for the scientific value (SV), potential educational use (PEU), potential touristic use (PTU), and 
degradation risk (DR) were calculated (Table 1). Next, the results were classified into one of four classes: very low, low, moderate, and high (Table 2).

The assessment indicates that:

- At present, the scientific value of almost all planned geosites is very low, with the exception of two localities (the quarry on Brusno Hill and the elements of the Greek Catholic church complex in Radruż), which were assigned a low value.

- In accordance with the adopted evaluation criteria, a vast majority of the geosites exhibit a low value for potential educational use, except for the quarry on Brusno Hill, which was assigned a moderate potential value. Five of the listed objects $(2,3,11,21$, and 22 , see Table 1$)$ had the lowest scores.

- Except for the quarry, all inventoried geosites were assigned a low value for potential touristic use.

- Low and the lowest values for degradation risk were assigned to as many as 16 and 9 of the 25 geosites, respectively.

It therefore seems necessary to develop appropriate criteria for a more comprehensive assessment of the cultural geosites. It can be assumed that the degree of attractiveness of the designed geosites analysed in the study would significantly increase if the assessment included cultural features, e.g. their connection with the history of the region and the local modes of production activities (e.g. crafts/industry), the material heritage (monuments), and the immaterial heritage (tradition, folklore), as well as the specific features of the local community (national and religious diversity). Such attempts have already been made, as evidenced by investigations conducted by Dmytrowski and Kicińska ( 2011) as well as Łabęcka and Terpiłowski (2017).

\section{Discussion}

The example of the use of the stonemasonry heritage of Brusno Stare described in this paper represents the increasingly popular trend of creating cultural geosites (Nita and Myga-

Fig. 3 The conceptual spatialtemporal model illustrating the holistic approach to unique cultural geosites
Piatek 2014; Mero et al. 2018). Among the current list of world geoparks, only some were created exclusively based on geosites with unique natural resources (UNESCO Global Geoparks List. http://www.unesco.org/new/en/naturalsciences/environment/earth-sciences/unesco-globalgeoparks/list-of-unesco-global-geoparks/). In a majority of geoparks, elements of nature and culture are combined, thus creating a sense of place, as underlined by Hose (2012) and Dowling (2013). Areas created in this way serve geotourism as defined by the National Geographic Council (after Mero et al. 2018).

This concept was taken into account in the project of the Kamienny Las na Roztoczu Geopark. The inventory indicated a complex of thematically related objects associated with the Stonework Centre in Brusno Stare, whose uniqueness and potential promote the development of geotourism.

The evaluation of the cultural geosites revealed their low geological and tourist attractiveness as well as scientific value, in contrast to data presented by Sá dos Santos et al. (2016) or Mero et al. (2018). This may result from the relatively poor knowledge of Eastern Roztocze and its tourist resources. An important factor that would facilitate their more effective use in tourism is the education of the residents and tourists in the area covering the natural and historical assets of the area.

The study emphasizes the importance of the holistic approach and proper interpretation of cultural geosites combining knowledge of geology, history, and culture. The stonemasonry heritage in Brusno Stare incorporates memories of the village and crafts that functioned and were recognizable in SE Poland in the past but do not exist at present (Fig. 3).

In the past, the residents used the easily processable local detrital limestones to specialize in stonemasonry and, hence, the ancient Stonework Centre in Brusno Stare became famous for the craft (Fig. 3a). This changed during and after World War II when the village ceased to exist. The absence of man led to the loss of the continuity and significance of all elements associated with the previous human presence (Fig. 3b). The place has fallen into oblivion and, consequently, the sense of place has been lost. Currently, the interest in the area's unique

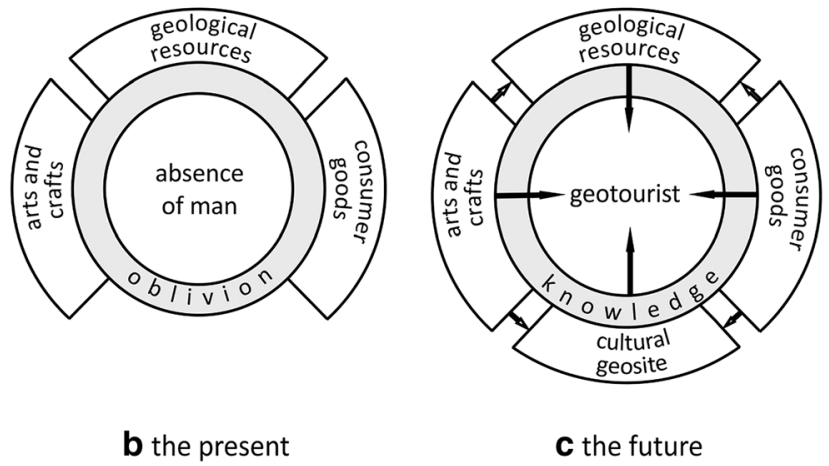

b the present
C the future

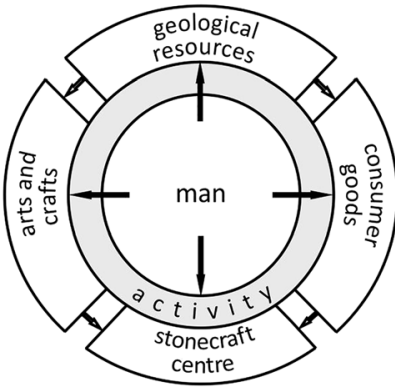

a the past 
heritage is a motivation for acquiring knowledge about local craftspeople and their products, which consequently ensures the proper interpretation of the place. Such actions bring together the preserved elements of the former humanenvironment relationships and provide awareness of their real importance. They should be the basis for creation of cultural geosites (Fig. 3c). These activities are part of geoeducation, shaping geotourists' attitudes in terms of proper interpretation and protection of geosites, which was emphasized by Gordon (2018). As demonstrated by the analysed example, the display of only geological resources at some geosites, without the cultural context, may lead to loss of the sense of place.

\section{Conclusions}

Here, in this study there have been described and valorised several new geosites associated with the ancient Stonework Centre in Brusno Stare. The valorisation results indicate their low geological, touristic, and scientific value. It would have been higher if a holistic approach had been applied, as emphasised in studies in other areas. Therefore, the results of the study confirm the necessity of creation of cultural geosites in their full natural, historical, and cultural context (see Fig. 3). Due to the growing tourists' interest in Eastern Roztocze (Brzezińska-Wójcik et al. 2017), taking steps for development of geotourism in this area seems advisable. The best solution would be to continue efforts to create the Kamienny Las na Roztoczu Geopark.

Open Access This article is licensed under a Creative Commons Attribution 4.0 International License, which permits use, sharing, adaptation, distribution and reproduction in any medium or format, as long as you give appropriate credit to the original author(s) and the source, provide a link to the Creative Commons licence, and indicate if changes were made. The images or other third party material in this article are included in the article's Creative Commons licence, unless indicated otherwise in a credit line to the material. If material is not included in the article's Creative Commons licence and your intended use is not permitted by statutory regulation or exceeds the permitted use, you will need to obtain permission directly from the copyright holder. To view a copy of this licence, visit http://creativecommons.org/licenses/by/4.0/.

\section{References}

Berthelsen A (1992) From Precambrian to Variscan Europe. In: Blundell D, Freeman R, Mueller S (eds) A continent revealed. The European Geotraverse. University Press, Cambridge, pp 153-164

Brilha J (2016) Inventory and quantitative assessment of geosites and geodiversity sites: a review. Geoheritage 8:119-134. https://doi. org/10.1007/s12371-014-0139-3

Brzezińska-Wójcik T, Kociuba W (2001) Transformation of the Roztocze segment of the Wieprz River valley (SE Poland) in the Pleistocene. Prz Geol 49(3):257-266
Brzezińska-Wójcik T, Skowronek E, Świeca A (2017) Diversity of the tourism potential and functions in the Roztocze region. Economic Problems of Tourism 40(4):65-81. https://doi.org/10.18276/ept.2017.4.40-06

Dmytrowski P, Kicińska A (2011) Geotourism valuation of unbiotic objects and their signification in prospect of geopark development. Problemy Ekologii Krajobrazu 29:11-20

Dowling R (2013) Global geotourism - an emerging form of sustainable tourism. Czech Journal of Tourism 2(2):59-79. https://doi.org/10. 2478/cjot-2013-0004

Gordon JE (2012) Rediscovering a sense of wonder: geoheritage, geotourism and cultural landscape experiences. Geoheritage 4: $65-77$

Gordon JE (2018) Geoheritage, geotourism and the cultural landscape: enhancing the visitor experience and promoting geoconservation. Geosciences 8(4):1-24. https://doi.org/10.3390/geosciences8040136

Gutowski J, Popadyuk I, Olszewska B (2005) Late Jurassic-earliest cretaceous evolution of the epicontinental sedimentary basin of SouthEastern Poland and Western Ukraine. Geological Quarterly 49:16-31

Hose TA (2012) 3G's for modern geotourism. Geoheritage 4:7-24. https://doi.org/10.1007/s12371-011-0052-y

Jankowski L, Margielewski W (2015) Tectonic position of the Roztocze region in the light of the evolution history of the Carpathian Foredeep. Biuletyn Państwowego Instytutu Geologicznego 462:728. https://doi.org/10.5604/08676143.1157483

Jawor G (2000) Osady prawa wołoskiego i ich mieszkańcy na Rusi Czerwonej w późnym średniowieczu. Uniwersytet Marii Curie Skłodowskiej, Lublin

Kawałko D (1995) Bruśnieński ośrodek kamieniarski. Zamojski Kwartalnik Kulturalny 3(45):5-8

Krapiec M, Jankowski L, Margielewski W, Urban J, Krapiec P (2012) The stone forest (Kamienny Las) Geopark in Roztocze and its geoturistic values. Prz Geol 60(9):468-479

Łabęcka K, Terpiłowski S (2017) Geotourism potential of the chalk mine in Mielnik (Podlasie lowland). Annales UMCS, B 72(2):57-71

Lew S (1967) Ludowy ośrodek kamieniarski w Bruśnie powiat Lubaczów. Rocznik Przemyski 11:193-225

Lugon R, Reynard E (2003) Pour un inventaire des géotopes du canton du Valais. Bulletin Murithienne 121:83-97

Mazur J (2008) Kresowe dziedzictwo. Kamieniarstwo bruśnieńskie. Muzeum Kresów w Lubaczowie 12, Lubaczów

Mero PC, Franco GH, Briones J, Caldevilla P, Domínguez-Cuesta MJ, Berrezueta E (2018) Geotourism and local development based on geological and mining sites utilization, ZarumaPortovelo, Ecuador. Geosciences 8(6):1-18. https://doi.org/10. 3390/geosciences 8060205

Musiał T (1987) Miocene of Roztocze (South-Eastern Poland). Biuletyn Geologiczny 31:5-140

Nita J, Myga-Piątek U (2014) Geotourist potential of post-mining regions in Poland. Bulletin of Geography - Physical Geography Series 7: 139-156 https://doi.org/10.2478/bgeo-2014-0007

Olszewski J (ed) (1912) Skorowidz przemysłowo-handlowy Królestwa Galicyi. Liga Pomocy Przemysłowej, Lwów https://www.pbc. rzeszow.pl/dlibra/publication/2639/edition/2483/content?ref=desc

Panizza M, Piacénte S (2003) Geomorfologia culturale. Pitagora, Bologna

Pralong JP (2004) Pour une mise en valeur touristique et culturelle des patrimoines de l'espace alpin: le concept d'«histoire totale». Histoire des Alpes 9:301-310

Pralong JP (2006) Geotourism: a new form of tourism untilising natural landscapes and based on imagination and emotion. Tour Rev 61(3): 20-25. https://doi.org/10.1108/eb058476

Reinfuss R (1989) Ludowa rzeźba kamienna w Polsce. Zakład Narodowy im, Ossolińskich, PAN, Instytut Sztuki, Wrocław

Reynard E, Regolini-Bissig G, Kozlik L, Benedetti S (2009) Assessment and promotion of cultural geomorphosites in the Trient Valley 
(Switzerland). Memorie Descrittive della Carta Geologica d'Italia $87: 181-189$

Sá dos Santos WF, de Souza CI, Brilha JB, Leonardi G (2016) Inventory and assessment of Palaeontological sites in the Sousa Basin (Paraíba, Brazil): preliminary study to evaluate the potential of the area to become a geopark. Geoheritage 8(4):315-332. https://doi. org/10.1007/s12371-015-0165-9

Skorowidz miejscowości Rzeczpospolitej Polskiej (1924) Województwo Lwowskie, 13. Główny Urząd Statystyczny Rzeczpospolitej Polskiej, Warszawa. http://pbc.biaman.pl/dlibra/docmetadata?id= $3113 \&$ from $=$ publication

Skowronek E, Furtak T (2009) Determinants of change in the landscape of the Polish-Ukrainian borderland as exemplified by Rawa Roztocze. Journal of Borderlands Studies 24(2):106-125

Skowronek E, Krukowska R, Świeca A (2003) Transformations of cultural landscape: the case of the Polish-Ukrainian borderland. In: Palang H, Fry GLA (eds) Landscape interfaces. Cultural Heritage in Changing Landscapes. Kluwer Academic Publishers, Dordrecht Harbound, pp 71-91

Snyder T (1999) "To resolve the Ukrainian problem once and for all": the ethnic cleansing of Ukrainians in Poland, 1943-1947. J Cold War Stud 1(2):86-120

Sulimierski F, Chlebowski B, Walewski W (eds) (1881) Słownik geograficzny Królestwa Polskiego i innych krajów słowiańskich,
Tom 2. Sulimierski and Walewski, Warszawa. http//dir.icm.edu.pl/ Slownik_geograficzny/Tom_II/

Sulimierski F, Chlebowski B, Walewski W (eds) (1884) Słownik geograficzny Królestwa Polskiego i innych krajów słowiańskich, Tom 5. Sulimierski, Chlebowski, and Walewski, Warszawa http:// dir.icm.edu.pl/Slownik_geograficzny/Tom_V/

Telecka M (2017) Geology in the art of Easter Island; geotouristic aspect. Annales UMCS, B 72(2):73-96

UNESCO Global Geoparks list. http://www.unesco.org/new/en/naturalsciences/environment/earth-sciences/unesco-global-geoparks/listof-unesco-global-geoparks/. Accessed 29 October 2018

UNESCO World Heritage List. http://whc.unesco.org/en/list/1424. Accessed 15 October 2019

Wesołowska M, Flaga M (2018) Demographic and social degradation in the Lublin province as a peripheral area of East Poland. Bulletin of geography. Socio-economic Series 41:7-27. https://doi.org/10. 2478/bog-2018-0023

Wysocka A, Jasionowski M, Peryt T (2007) Miocene of the Roztocze Hills. Biuletyn Państwowego Instytutu Geologicznego 422:79-96

Zgłobicki W, Warowna J, Baran-Zgłobicka B, Gajek G, Jezierski W (2015) Cultural tourism and geotourism. Tourist value of cultural geosites in Poland. Turystyka Kulturowa 6:51-67 